\title{
Process Simulate ako nástroj pre optimalizácia vybraného pracoviska v podniku
}

\author{
Jozef Trojan ${ }^{1}$, Peter Trebuňa ${ }^{1}$, Marek Mizerák ${ }^{1}$, Richard Duda ${ }^{1}$ \\ 1 Technická univerzita v Košiciach \\ Park Komenského 9, 04200 Košice, Slovensko \\ jozef.trojan@tuke.sk \\ peter.trebuna@tuke.sk \\ marek.mizerak@tuke.sk \\ richard.duda@tuke.sk
}

\begin{abstract}
Anotace: Digitálna budúcnost' priemyslu je jedna z najnaliehavejších tém vo svete, aj na Slovensku. Preto sme sa rozhodli $s$ pomocou nástroja Tecnomatix Process Simulate modelovat', analyzovat' a verifikovat' procesy na úrovni výrobnej továrne až na úroveň výrobných liniek a pracovných staníc. Pomocou tohto simulačného softvéru a získaných poznatkov o najnovších technológiách, vytvoríme simulačný model produkčného pracoviska, $v$ ktorom zakomponujeme inteligentné prvky konceptu „Priemysel 4.0”. Následne si ukážeme ako tieto prvky dokážu optimalizovat' výrobu.
\end{abstract}

\section{1 Úvod}

My žijeme $v$ úžasnom čase - $v$ ére, ked' sa radikálne zmeny $v$ technológiách odohrávajú pred našimi očami a to, čo sa včera zdalo fantastické, je dnes už skutočným projektom, na ktorom pracujú inovatívne spoločnosti a zajtra sa stáva prirodzeným spoločným javom, bez ktorého si už nevieme predstavit' náš život.

Štvrtá priemyselná revolúcia bude mat' zásadný vplyv na celkovú štruktúru svetového hospodárstva, a ak chceme byt' medzi jej vedúcimi predstavitel'mi, musíme pochopit' smer, ktorým sa bude technologický vývoj $v$ nasledujúcich rokoch odohrávat' a ktoré prelomové inovácie nás čakajú v budúcnosti.

Digitalizácia otvára výrobným továrňam nové príležitosti pre zrýchlenie a zefektívnenie výroby. Úlohou človeka je zabezpečit' zodpovednú "inteligentnú" infraštruktúru na novodobé požiadavky. Preto je dôležité porozumiet' vplyvu digitalizácie na podnikanie firiem či na ekonomiku, vplyvu inteligentných technológií na okolité prostredie a jednotlivé procesy. Digitalizácia zásadne ovplyvní ako budeme v budúcnosti vyrábat' produkty a ako budú vyzerat' energetické siete, ale prinesie aj zásadné ekonomické a sociálne zmeny.

V našom článku sa budeme venovat' optimalizácii vybraného pracoviska vo výrobnom podniku prostredníctvom softvéru Tecnomatix Process Simulate od spoločnosti Siemens. Dané pracovisko nutne potrebovalo technologickú a softvérovú modernizáciu, odstránenie niektorých zbytočných úkonov 
a zníženie vel'kého počtu operácií. V spomínanom softvéri sme si vytvorili súčasný stav pracoviska a postupne sme ho pretvárali na modernejší a úspornejší požadovaný stav. Nakoniec sa nám podarilo dosiahnut' stanovený ciel', ktorého výsledky budú bližšie rozobraté v článku.

\section{Pôvodný stav pracoviska}

Súčasný stav pracoviska je z hladiska inovatívnych technológií zastaraný a existujú široké možnosti jeho modernizácie. Mnohé úkony sa tu vykonávajú ručne, ale časom je možné túto prácu nahradit' umelou inteligenciou high-tech robotov.

Pôvodný layout pracoviska a materiálový tok označený červenými šípkami môžeme vidiet' na Obrázku 1.

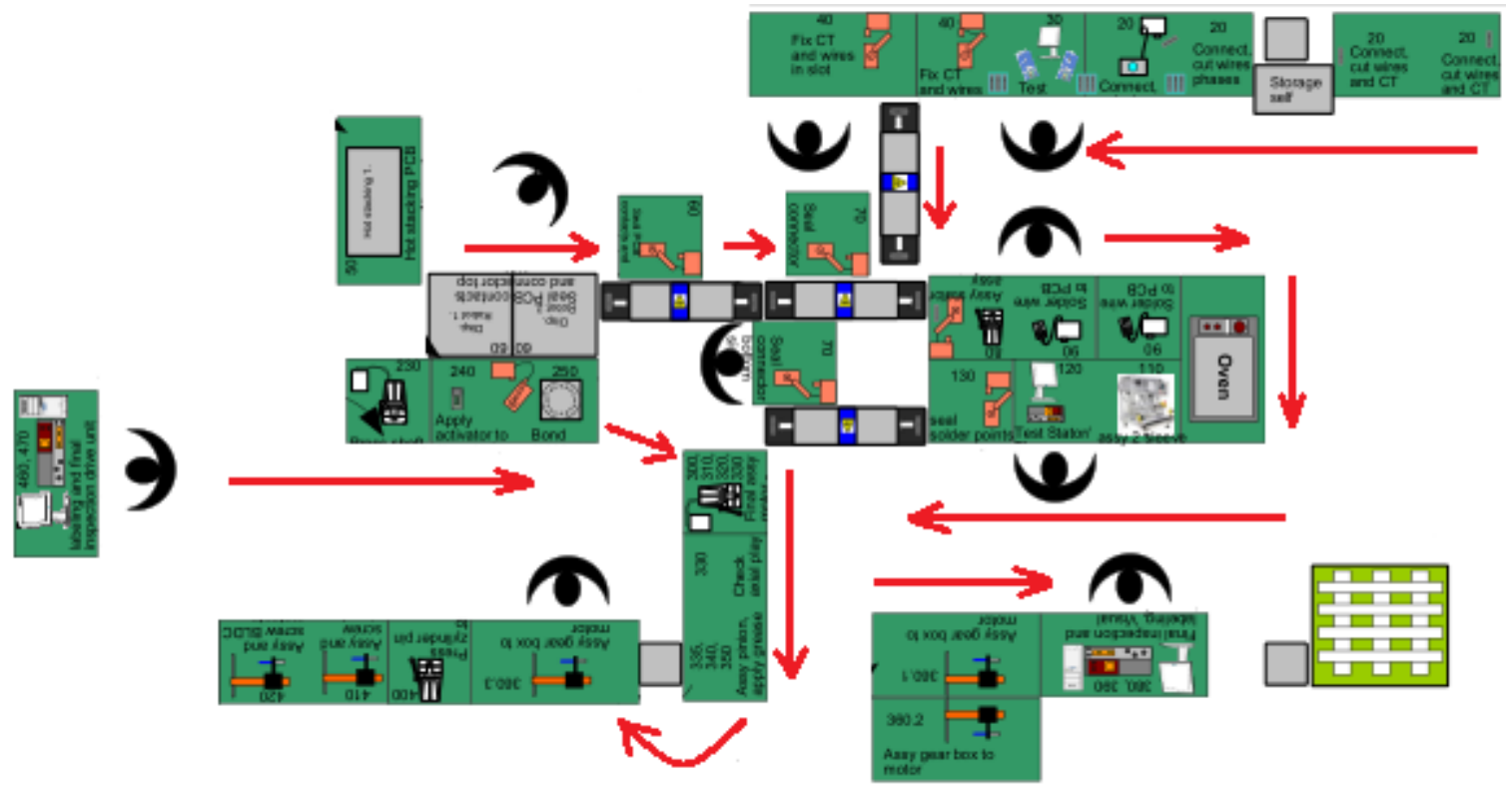

Obrázok 1 - Súčasný layout pracoviska

Pracovisko na výrobu elektromotora pozostáva z 27 operácií, ktoré sa označujú vel'kými písmenami PI a príslušným číslom danej operácie. Takto označený postup výroby je od vstupnej kontroly, cez lisovanie, testovanie, vytvrdzovanie, lepenie, montáž až po výstupnú kontrolu. $V$ tabul'ke číslo 1 môžeme vidiet' príslušné časy, za ktoré prebiehajú operácie na pracoviskách a celkovú dobu výroby motora. Farebne sú označené operácie, ktoré budeme následne združovat'. 
Tabul'ka 1 - Časy výroby na jednotlivých pracoviskách

\begin{tabular}{|l|l|}
\hline Označenie operácie & Čas (min) \\
\hline PI - 20 & 0,7725 \\
\hline PI - 20_2 & 0,2360 \\
\hline PI - 30 & 0.2390 \\
\hline PI - 40 & 0,268 \\
\hline PI - 50 & 0,1967 \\
\hline PI - 60 & 0,1336 \\
\hline PI - 70 & 0,2813 \\
\hline PI - 80 & 0,1196 \\
\hline PI - 90 & 0,3042 \\
\hline PI - 100 & 0,0333 \\
\hline PI - 110 & 0,2525 \\
\hline PI - 120 & 0,1801 \\
\hline PI - 130 & 0,0717 \\
\hline PI - 220 & 0,1301 \\
\hline PI - 230 & 0,1460 \\
\hline PI - 240 & 0,144 \\
\hline PI - 250 & 0,2661 \\
\hline PI - 300 & 0,0100 \\
\hline PI - 310 & 0,0396 \\
\hline PI - 320 & 0,0333 \\
\hline PI - 330 & 0,283 \\
\hline PI - 335 & 0,0457 \\
\hline PI - 340 & 0,0765 \\
\hline PI - 350 & 0,0693 \\
\hline PI - 360 & 0,4438 \\
\hline PI - 380 & 0,192 \\
\hline PI - 390 & 0,0929 \\
\hline Celková doba výroby motora & $\mathbf{5 , 3 1 5 8}$ \\
\hline & \\
\hline
\end{tabular}




\section{Novo navrhnutý stav}

Po zlúčení operácií, ktoré boli vyznačené žltou, modrou a fialovou farbou v tabul'ke sme vytvorili ucelenejší a prehl'adnejší layout ako aj plynulejší materiálový tok výrobou. Farebne označené operácie sme nahradili troma vysoko presnými robotickým strojmi, ktoré vykonávajú prácu ovel'a rýchlejšie a efektívnejšie (Obrázku 2). Úlohou človeka ostalo vkladanie materiálu na určité definované miesta $v$ týchto strojoch a následne vybratie hotových výrobkov.

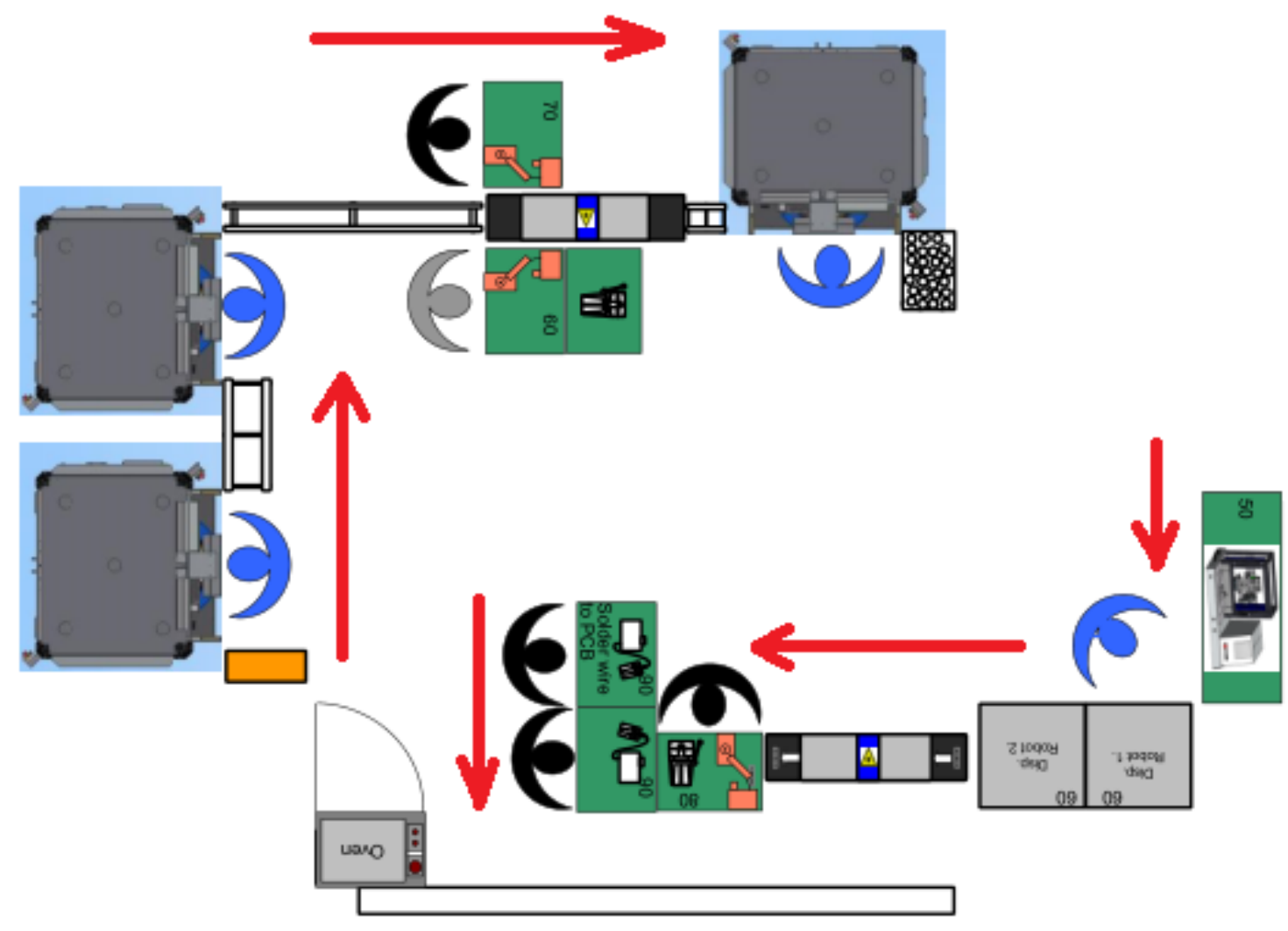

Obrázok 2 - Novo navrhnutý layout pracoviska

$\checkmark$ tabul'ke číslo 2 môžeme vidiet' výrobné časy na jednotlivých pracoviskách po zmene. Vidíme, že počet operácií sa znížil z 27 na 11, čo je viac ako o polovicu. Nahradenie manuálnej práce robotmi nám umožnilo skrátenie času výroby jedného elektromotora z 5,38 minúty na 2,24 minúty, čo má obrovský význam pre túto spoločnost'. 
Tabul'ka 2 - Časy výroby na jednotlivých pracoviskách po zmene

\begin{tabular}{|l|l|}
\hline Označenie operácie & Čas $(\mathrm{min})$ \\
\hline $\mathrm{PI}-30$ & 0,2390 \\
\hline $\mathrm{PI}-40$ & 0,2812 \\
\hline $\mathrm{PI}-50$ & 0,2589 \\
\hline $\mathrm{PI}-60$ & 0,1777 \\
\hline $\mathrm{PI}-70$ & 0,2893 \\
\hline $\mathrm{PI}-80$ & 0,2951 \\
\hline $\mathrm{PI}-90$ & 0,3948 \\
\hline $\mathrm{PI}-100$ & 0,0259 \\
\hline Stroj 1 & 0,2666 \\
\hline Stroj 2 & 0,2666 \\
\hline Stroj 3 & 0,2666 \\
\hline Celková doba výroby motora & 2,2415 \\
\hline
\end{tabular}

\section{Záver}

Použitie robotov dnes pokrýva takmer všetky odvetvia a úlohy. Vd'aka rýchlemu rozvoju robotiky sa interakcia medzi človekom a strojmi čoskoro stane bežnou každodennou praxou. Preto sme sa aj my rozhodli pre nahradenie zložitých výrobných operácií robotizovanými jednotkami, čo malo za následok plynulejší materiálový tok a zjednodušenie výrobného procesu. Po porovnaní výrobných časov pred a po zavedení robotov sme zistili skrátenie času výroby jedného elektromotora o viac ako 3 minúty, čo firme umožní vyrábat' viac kusov za rovnaký čas.

\section{Pod'akovanie}

Tento príspevok vznikol za podpory grantových projektov APVV-17-0258, APVV-19-0418, VEGA 1/0438/20 a KEGA 001TUKE-4/2020

\section{Použitá literatura}

[1] EDL, M., LERHER, T., ROSI, B. Energy efficiency model for the mini-load automated storage and retrieval systems. International Journal of Advanced Manufacturing Technology, 2013, 1-19. ISSN: 0268-3768.

[2] MARKULIK, Š., CEHLÁR, M., KOZEL, R. Process approach in the mining conditions. Acta Montanistica Slovaca, 2018, 23(1), 46-52. ISSN 1335-1788. 
[3] STRAKA, M., KHOURI S., ROSOVA A., CAGANOVA D., CULKOVA K. Utilization of computer simulation for waste separation design as a logistics system. International Journal of Simulation Modelling, 2018, 17(4), 583-596.

[4] KŁOS, S. Implementation of the AHP method in ERP-based decision support systems for a new product development. Communications in Computer and Information Science, 2015. ISSN 1865-0929.

[5] CMOREJ, T., PANDA, A., BARON, P., POOR, P., POLLAK, M. Surface finishing of $3 \mathrm{~d}$ printed sample manufacturated by fused deposition modeling. MM Science Journal, 2017, 5, 1981-1985. doi: 10.17973/mmsj.2017_12_201753.

[6] BUCKOVA, M., KRAJCOVIC, M., EDL, M. Computer simulation and optimization of transport distances of order picking processes. Procedia Engineering, 2017, 192, 69-74. doi: 10.1016/j.proeng.2017.06.012.

[7] FUSKO, M., BUCKOVA, M., GASO, M., KRAJCOVIC, M., DULINA, L., SKOKAN, R. Concept of Long-Term Sustainable Intralogistics in Plastic Recycling Factory. Sustainability, 2019, 11(23), 6750. doi: 10.3390/su11236750.

[8] MANLIG, F., SLAICHOVA, E., KOBLASA, F., VAVRUSKA, J. Innovation of business processes by means of computer-aided simulation. Novel Trends In Production Devices And Systems, Applied Mechanics and Materials, 2014, 474, 67-72. doi: 10.4028/www.scientific.net/AMM.474.67. 